2016

Seasonal shifts in the movement and distribution of green sea turtles Chelonia mydas in response to anthropogenically altered water temperatures

Daniel P. Crear

Daniel D. Lawson

Jeffrey A. Seminoff

et al

Follow this and additional works at: https://scholarworks.wm.edu/vimsarticles

Part of the Marine Biology Commons 


\title{
Seasonal shifts in the movement and distribution of green sea turtles Chelonia mydas in response to anthropogenically altered water temperatures
}

\author{
Daniel P. Crear ${ }^{1, *}$, Daniel D. Lawson ${ }^{2}$, Jeffrey A. Seminoff ${ }^{3}$, Tomoharu Eguchi ${ }^{3}$, \\ Robin A. LeRoux ${ }^{3}$, Christopher G. Lowe ${ }^{4}$ \\ ${ }^{1}$ Virginia Institute of Marine Science, College of William \& Mary, PO Box 1346, Gloucester Point, Virginia 23062, USA \\ ${ }^{2}$ Protected Resources Division, West Coast Regional Office, National Marine Fisheries Service, \\ National Oceanic and Atmospheric Administration, 501 West Ocean Blvd., Suite 4200, Long Beach, California 90802, USA \\ ${ }^{3}$ Protected Resources Division, Southwest Fisheries Science Center, National Marine Fisheries Service, \\ National Oceanic and Atmospheric Administration, 8901 La Jolla Shores Dr., La Jolla, California 92037, USA \\ ${ }^{4}$ Department of Biological Sciences, California State University 1250 Bellflower Blvd., Long Beach, California 90840, USA
}

\begin{abstract}
Anthropogenically altered water temperatures (AAWT) have the potential to affect the movement and distribution of marine ectothermic species. Green sea turtles (GSTs) Chelonia mydas are an ectothermic species observed inhabiting 2 sites with AAWT at the northern point of their geographical range in the eastern Pacific. An acoustic receiver array was deployed with temperature loggers at the San Gabriel River, Long Beach, CA, where 2 power plants discharge warm water into the river, and at the $7^{\text {th }}$ St. Basin, Seal Beach, CA, a dredged shallow basin with warmer water compared to surrounding coastal habitats during the summer months. Juvenile GSTs $(\mathrm{n}=$ 22 , straight carapace length $=45.2$ to $96.8 \mathrm{~cm}$ ) were tagged with acoustic transmitters. Turtles in the basin migrated into the river during winter months when temperatures dropped below $15^{\circ} \mathrm{C}$. During the winter, turtles were most frequently detected at the river receiver stations adjacent to and downstream of the power plants. This suggests that GSTs use the warm effluent as a thermal refuge, avoiding colder areas upstream of the power plants and near the river mouth. In the summer, turtles were most frequently detected at receiver stations upstream of the power plants, potentially exploiting areas of the river with higher primary productivity. AAWT sustain the northernmost aggregation of GSTs in the eastern Pacific year round; however, based on GST thermal tolerance, this population is expected to change their movement patterns when the power plants discontinue discharging warm water by 2029.
\end{abstract}

KEY WORDS: Thermal refuge · Ectotherm · Warm water effluent · Power plants · Acoustic telemetry · Foraging aggregation

\section{INTRODUCTION}

Intense coastal development has led to anthropogenic alteration of near-shore water temperature in many natural habitats. For example, the channelization and concrete-lining of rivers increase water temperatures when shallow, slow-moving water flowing over the concrete-lined rivers warms from solar radiation and heat surrounding estuarine habitats (Leopold 1968, Allen \& Feddema 1996). Further, water-cooled electricity generating plants (herein referred to as 'power plants') that use once-through cooling (OTC), draw local lake, river or ocean water to cool steam generators, which results in discharge of heated water back into the natural environment, significantly altering surrounding ambient water temperatures (Kelso \& Milburn 1979, Ma et al. 1998).

Anthropogenically altered water temperatures (AAWT) can directly affect the distribution, abundance, species composition, and behavior of aquatic 
species. Areas of warmer water may act as thermal refuges for many aquatic species, whereby they use these habitats to avoid colder or unfavorable habitats. For instance, to reduce the risk of cold stress syndrome (CSS), aggregations of over 50 manatees in the winter in Florida are attracted to power plant discharge outflows (Bossart et al. 2004, Laist \& Reynolds 2005). Ectotherms such as sea turtles and elasmobranchs have been observed to seek out and take refuge within anthropogenically warmed waters, which is expected to alter metabolism and growth (Hight \& Lowe 2007, Eguchi et al. 2012, Jirik \& Lowe 2012, MacDonald et al. 2012).

Juvenile green sea turtles (GSTs) Chelonia mydas are fully ectothermic and more sensitive to changes in water temperatures than larger subadults and adults, which exhibit regional endothermy (Standora et al. 1982, Spotila \& Standora 1985). These larger individuals (mass $>120 \mathrm{~kg}$ ) are able to generate heat while swimming and retain heat from peripheral muscles and thermal inertia (Standora et al. 1982, Wallace \& Jones 2008). However, smaller GSTs (mass range: 2 to $60 \mathrm{~kg}$ ) have the potential to overheat and become inactive and stressed when temperatures reach a range between 25 and $40^{\circ} \mathrm{C}$ (Heath \& McGinnis 1980, Spotila et al. 1997). Despite their thermoregulatory capabilities, eastern Pacific GSTs, which experience cooler temperatures, become inactive or enter a state of torpor when temperatures drop below approximately $15^{\circ} \mathrm{C}$ (Felger et al. 1976, Mrosovsky 1980). This behavior has also been observed in a laboratory setting when temperatures were gradually reduced from 26 to $11^{\circ} \mathrm{C}$ (Moon et al. 1997). Between water temperatures of 7.3 to $10^{\circ} \mathrm{C}$, smaller GSTs (mass range: 2 to $59 \mathrm{~kg}$, size range: 25 to $75 \mathrm{~cm}$ straight carapace length) become cold stunned, a state where turtles begin to lose their buoyancy control, respiratory function, and the ability to swim and dive (Mrosovsky 1980, Witherington \& Ehrhart 1989, Southwood et al. 2003). To avoid these physiological consequences associated with colder waters, especially for smaller, more thermally sensitive turtles, individuals search out and utilize environments that offer thermal refuges.

Juvenile GSTs in the northeastern Pacific recruit and spend 9 to $21 \mathrm{yr}$ within neritic habitats until reaching maturity (Seminoff et al. 2002). Those in the northernmost part of their range may be attracted to coastal anthropogenically warmed habitats, as has been observed in San Diego Bay where juvenile and adult GSTs have been documented aggregating around the warm water effluent from the San Diego Bay OTC power plant (operational from 1960 to 2010)
(McDonald et al. 1994, Eguchi et al. 2010, TurnerTomaszewicz \& Seminoff 2012). This power plant was hypothesized to act as a thermal refuge for approximately 60 individuals (mass range: 12 to $241 \mathrm{~kg}$, size class: 44 to $110.4 \mathrm{~cm}$ straight carapace length), particularly during the colder winter months (Eguchi et al. 2010, 2012, MacDonald et al. 2012).

Although San Diego Bay has historically supported the northernmost residential population of the threatened GSTs in the eastern Pacific, an unknown number of individuals have been observed approximately $150 \mathrm{~km}$ north of San Diego within the San Gabriel River, Long Beach, CA and the Seal Beach National Wildlife Refuge (SBNWR), Seal Beach, CA. The San Gabriel River contains $6 \mathrm{~km}$ of estuarine habitat extending from the river mouth northwards before becoming concrete-lined (modified to function as a flood control channel). In addition, 2 power plant systems ( $3 \mathrm{~km}$ from the river mouth) discharge warm water effluent into the San Gabriel River via OTC, potentially providing GSTs with a warmer habitat than surrounding coastal habitats during winter months. The lower reaches of the San Gabriel River is lined with a rock riprap that supports a variety of algae and invertebrates (Turner \& Strachan 1969), which have been observed year-round and are known food sources for GSTs (Blumenthal et al. 2010, Lemons et al. 2011). However, the San Gabriel River does not support eelgrass beds (Zostera marina) (K. W. Merkel et al. unpubl. data), which are thought to be an important food source and common habitat component in some areas where GSTs forage (Musick \& Limpus 1997, MacDonald et al. 2012).

Within the SBNWR, GSTs have also been observed within a dredged saltwater pond ( $7^{\text {th }}$ Street Basin), which, because of its shallow shoals, allows water temperatures within the basin to get significantly warmer than the adjacent natural estuary in the summer, but colder in the winter (Jirik \& Lowe 2012). Unlike the San Gabriel River, the $7^{\text {th }}$ St. Basin has large patches of eelgrass throughout (K. W. Merkel et al. unpubl. data). To enter the $7^{\text {th }}$ St. Basin, animals have to swim through a concrete box culvert $(1.5 \times$ $2.4 \times 12.0 \mathrm{~m}$ ), which mutes tidal flow in and out of the $7^{\text {th }}$ St. Basin. Turtles are able to swim freely through the culvert, except during strong tidal changes. Once an animal leaves the $7^{\text {th }}$ St. Basin, it has to go through a network of channels to reach Anaheim Bay Harbor, which leads to the ocean, to then reach the San Gabriel River (see Fig. 1).

As GST populations increase (Seminoff et al. 2015) and efforts to restore lost estuarine and marsh habitats improve, it is critical to understand how AAWT 
affect habitat selection of this threatened species. This need is heightened in this highly urbanized environment as long-term residency in these areas can expose GSTs to higher levels of environmental contaminants. Furthermore, power plants along the southern California coastline, including those along the San Gabriel River, will be required to phase out their OTC systems by 2029. Therefore, understanding how GSTs use this habitat before it is altered can provide a baseline that can be compared to future studies in the area. Based on the thermal characteristics of these highly urbanized and altered habitats, it was hypothesized that GSTs would (1) move from the $7^{\text {th }}$ St. Basin to the San Gabriel River when temperatures in the $7^{\text {th }} \mathrm{St}$. Basin drop below $15^{\circ} \mathrm{C}$, (2) use the San Gabriel River year round, (3) prefer the warmest areas in the river, (adjacent to the power plant discharge outflows) during the colder months, and (4) use more space during the warmer summer months compared to the colder winter months in the river.

\section{MATERIALS AND METHODS}

\section{Turtle capture and tagging}

To capture GSTs, entanglement nets were deployed by permitted National Oceanic and Atmospheric Administration (NOAA) - National Marine Fisheries Service (NMFS) researchers (Permit \# 14510) within the San Gabriel River $\left(33^{\circ} 45^{\prime} \mathrm{N}, 118^{\circ} 05^{\prime} \mathrm{W}\right)$ and $7^{\text {th }}$ St. Basin $\left(33^{\circ} 44^{\prime} \mathrm{N}, 118^{\circ} 03^{\prime} \mathrm{W}\right)$ from June 2012 to August 2014 (Fig. 1). When turtles were caught, they were immediately removed from the net and a series of biological data (i.e. length, width, weight, blood sample, tissue sample) were collected. Each individual was tagged with a subcutaneous passive integrative transponder (PIT) tag (Avid), a flipper ID tag (Style 681, National Band and Tag Company), and an external coded acoustic transmitter (Heupel et al. 2010), with unique IDs (V16-4L, $16 \times 68 \mathrm{~mm}$, frequency: $69 \mathrm{kHz}$, random pulse rate: $5-15,15-35,15-45$, or $40-80 \mathrm{~s}$, estimated battery life: 200, 203, 643, 1550, or $1542 \mathrm{~d}$, power output: $152 \mathrm{~dB}, 24 \mathrm{~g}$ in air, Vemco). New acoustic transmitters were fitted to recaptured turtles whose transmitters were shed. An acoustic monitoring period ended for an individual if the transmitter was deemed to have fallen off the turtle (transmitter detected at the same acoustic receiver for over a month), the battery died, or the turtle left the acoustic array and did not return. All turtles were released at the site of capture.

\section{Acoustic monitoring and environmental parameters}

Initially, an array of 6 autonomous omni-directional underwater acoustic receivers (VR2W, Vemco) were deployed in the San Gabriel River in July 2012 to detect tagged turtles. To increase receiver coverage along the entire accessible portions of the river $(6 \mathrm{~km})$, the receiver array was redistributed and 9 more receivers were added in November 2012. Based on receiver range testing, receiver stations were spaced 300 to $600 \mathrm{~m}$ apart and stretched from the mouth to where the riverbed turns to concrete (the entire area accessible to turtles) in the San Gabriel River. To detect turtles that were migrating from the $7^{\text {th }}$ St. Basin to the ocean within SBNWR, 5 acoustic receivers were placed at choke points, extending from the $7^{\text {th }}$ Street Basin out to the ocean through Anaheim Bay (Fig. 1). Receivers were anchored $<1 \mathrm{~m}$ from the seafloor with two $25 \mathrm{~kg}$ sandbags at each station with the exception of 2 receiver stations located in Anaheim Bay Harbor, which were attached to a navigational buoy chain

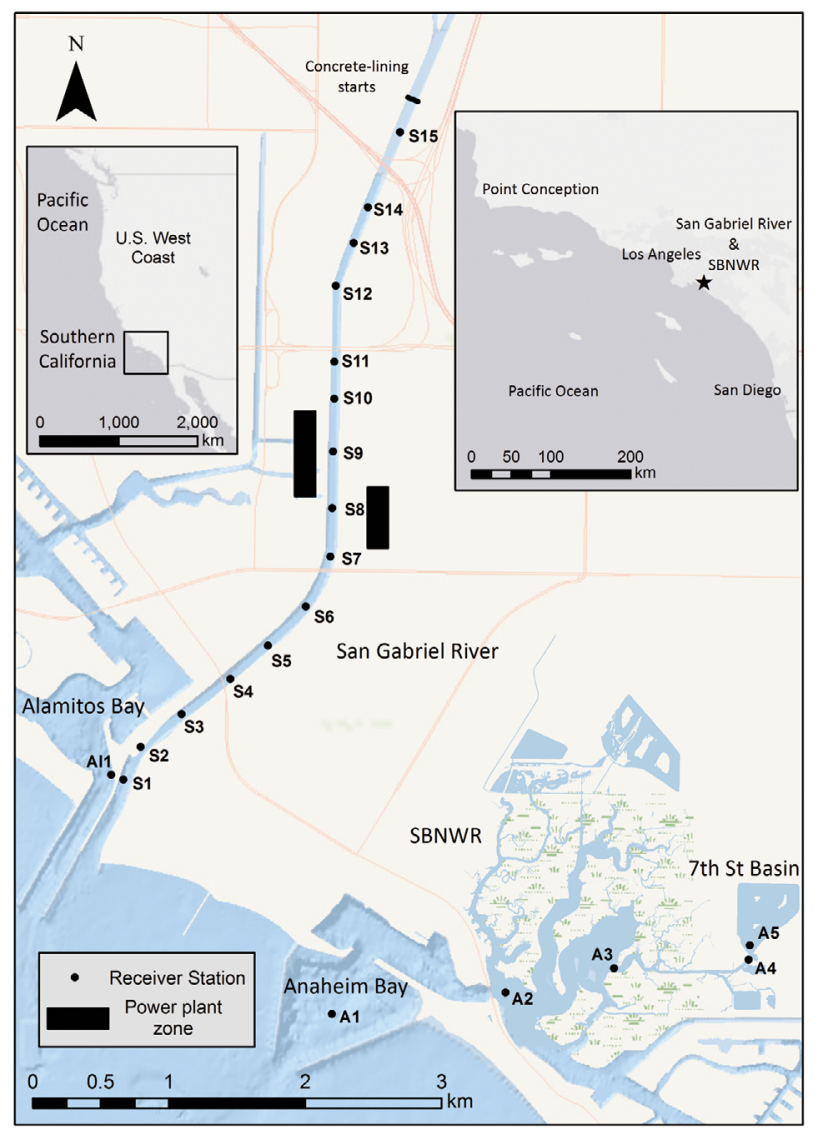

Fig. 1. Location of receiver stations within the San Gabriel River, Anaheim Bay, the $7^{\text {th }}$ St. Basin within the Seal Beach National Wildlife Refuge (SBNWR), and Alamitos Bay 
midwater. An additional receiver was added in September 2013 at the entrance of Alamitos Bay to detect the movements of turtles from the San Gabriel River into this neighboring embayment.

Receivers were range tested at high and low tides to determine the detection range at various locations along the river (range: $50-600 \mathrm{~m}$ ), the $7^{\text {th }}$ St. Basin (range: 10-50 m), and Anaheim Bay (range: 50$650 \mathrm{~m}$ ). Temperature data loggers (HOBO Pendant Data Logger, UA-001-64K, Onset Computers) were attached to every acoustic receiver and set to record temperatures every hour, in order to get a detailed understanding of how water temperature differed between and within sites over the course of the study. Water temperatures were interpolated throughout the entire $6 \mathrm{~km}$ stretch of estuarine river using inverse distance weighting (IDW) in ArcGIS 10.2.

\section{Data analysis}

Movements from the basin to the river

Using data from the initial (6 receivers in the river) and reformed (15 receivers in the river) arrays, the number of turtles that left the $7^{\text {th }}$ St. Basin and swam into the San Gabriel River during the winter and summer months was determined from June 2012 to August 2014. On days during which turtles left the $7^{\text {th }}$ St. Basin, mean temperature $( \pm 1$ day of departure) was compared between the 2 sites and to that of the coastline of Long Beach using NOAA navigational buoys (NOAA SST data was obtained from http:// tidesandcurrents.noaa.gov).

\section{Departures from the river}

To maintain consistent receiver coverage among turtles, only individuals detected in the reformed array after November 2012 were included in further analyses. The frequency of turtle departures from the river and the duration of absences were determined for each season and each individual. A departure from the river and into the ocean was determined when there was no detection of the individual for an hour and the last detection was at the first (S1) or second receiver station (S2) at the river mouth (Fig. 1). Receiver coverage was continuous among the first 3 receiver stations at the river mouth; therefore, if a turtle was not detected for at least an hour at the river mouth there was a high chance the turtle had left the river. A mixed effects model was used to compare the amount of time turtles spent outside the river among seasons (Spring: Mar-May; Summer: Jun-Aug; Fall: Sep-Nov; Winter: Dec-Feb) with turtle as a random effect.

\section{Within-river movements}

Individuals with fewer than $30 \mathrm{~d}$ of detections within the reformed array were removed from further analyses to ensure each individual had an adequate number of detections to be compared temporally and eliminate biases of individuals with short transmitter retention. To determine whether GSTs were selecting the warm water effluent from the power plants within the river, each warm water discharge event was documented, the extent of the warm water effluent up or down the river was identified, and the percent of detections of all turtles in and out of the warm water effluent at each receiver station was determined. Discharge events were identified based on the water temperatures in the river (recorded by temperature loggers attached to each acoustic receiver) near the power plants' discharge outflows using the following criteria: (1) the temperature at any source receiver station (S7, S8, S9, or S10 which bracket the power plants' discharge outflows, Fig. 1) was greater than $85 \%$ of the maximum temperature in the river that week; (2) the temperature increased by at least $1^{\circ} \mathrm{C}$ from the previous hour at that source receiver station; and (3) the warm water effluent reached a subsequent receiver station within the next $2 \mathrm{~h}$. The extent of the warm water effluent (from tidal flow or net river movement) was identified as the southernmost and northernmost receiver stations where the previous criteria were met. The percent of detections from all turtles for each hour for each receiver station was then calculated. A linear mixed effects model was used to compare the percent of detections in the warm water effluent to that of outside the warm water effluent using the package nlme in R v.3.0.1 (Pinheiro et al. 2013). Due to the non-independence of detections at each station, receiver station was the random effect in the model.

Weekly presence of turtles within the San Gabriel River was characterized as the proportion of days per week at each receiver station that a turtle was detected. An individual was considered present at that receiver station if that turtle was detected at least twice in one hour at that receiver station in that day. Mean weekly temperature was determined at each receiver station throughout the duration of the study. Each receiver station was identified by the distance from the river mouth. To test whether water 
temperature played an important role in the distribution of turtles within the river, the degree to which water temperature explained variation in the presence of turtles at various receiver stations throughout the river was evaluated. Two models were compared, the first (Model-I) not including temperature as one of its predictor variables and the second model (Model-II) including temperature in the set of predictor variables. Model-I was a generalized additive model (GAM I) in which expected weekly presence at a particular receiver station was modeled as a smooth function of distance from the mouth and season. These predictor variables are expected to have synergistic effects; therefore, a spline-based smoothing function was used on the combined values of the predictor variables, rather than separate smoothing functions associated with each predictor (Wood 2006). Because the data represented a series of observations from 13 individual turtles, in each model, the smoothing function was allowed to vary by turtle. Model-II (GAM II) included the same predictors (distance from the mouth and season) as GAM I with the addition of weekly temperature. Models were fit using the program R v.3.0.1 using the mgcv package (Hastie \& Tibshirani 1990, Wood 2011). A quasi-binomial distribution was used for the link function because weekly presence was quantified as a proportion. A drop-in deviance test was used to compare whether including temperature (GAM II) significantly improved model fit.

The weighted mean position in the river $(\mathrm{km}$ from the river mouth) of all turtles combined was calculated for each month throughout the study using a modified mean-position algorithm described in Simpfendorfer et al. (2008). This algorithm uses the mean detection efficiency (no. of valid detections / no. of synchs) of each receiver each month and the distance each receiver is from the river mouth to calculate a weighted mean position (herein referred to as 'mean location in the river') of all tagged turtles each month. For a code to be recognized, the transmitter has to have a valid synchronization period (a fixed time interval between the first 2 pulses in the transmitter's pulse train - 'synchs'), which is rarely replicated by underwater noise. When the number of valid synchs does not have corresponding valid detections, the remaining transmitter's pulse train was either interrupted by another transmitter's pulse train or by background noise.

To determine if turtles were associating with the warmest temperature year round, the monthly mean location in the river of turtles and the distance of the receiver station from the river mouth with the highest mean temperature each month were compared using a Pearson's product-moment correlation. In addition, mean location in the river of all tagged turtles was calculated per hour for each season to determine whether turtles preferred different locations in the river at different times of the day and whether these locations differed seasonally. A linear model was used to determine whether season and hour affected the hourly mean location of turtles in the river, and Tukey's post-hoc tests were used to determine pairwise comparisons. Both tests were completed in $\mathrm{R}$ v. 3.0.1 using the nlme (Pinheiro et al. 2013) and multcomp (Hothorn et al. 2008) packages, respectively. All statistics were evaluated at significance levels of $\alpha=0.05$.

As a proxy for activity, a daily maximum linear river use measure for each tagged turtle was calculated. Maximum river use was determined for each individual by calculating the distance between the southernmost (closest to river mouth) and northernmost (farthest from river mouth) receiver stations the turtle was detected in one day (possible range of values: 0 to $6164 \mathrm{~m}$ ). Because of the temporally and spatially dynamic nature of temperature in the river over the course of the study, several different statistics were computed including daily standard deviation (SD), mean, maximum, minimum, and median temperatures. SD was used to assess whether temperature variability influenced turtle activity. Linear mixed effects models were used to determine if the interaction between various temperature parameters and month significantly affected maximum river use using the package nlme in R v.3.0.1 (Pinheiro et al. 2013). Each individual turtle was treated as a random effect to account for non-independence. Models were compared using Akaike's information criteria (AIC). Where necessary, statistical test assumptions were assessed and were met for each statistical analysis.

\section{RESULTS}

Twenty-two individual GSTs $\left(25\right.$ captures: $7^{\text {th }}$ St. Basin: $\mathrm{n}=7$, San Gabriel River: $\mathrm{n}=18$ ) were tagged with acoustic transmitters and monitored from June 2012 to August 2014 (mean transmitter retention on turtles was $95 \pm 132 \mathrm{~d}_{\text {; }}$ range: 4 to $649 \mathrm{~d}$, median: 54 d) (Table 1). Of the individuals caught and tagged, $96 \%$ were juveniles. Three individuals were recaptured, all of which had shed transmitters. One of the recaptured individuals was initially caught and tagged in the San Gabriel River on 25 June 2012 (monitored until 4 July 2012) and then captured 
Table 1. Summary of the 22 captured, tagged and monitored turtles from 25 June 2012 to 31 August 2014. 'Old' represents turtles monitored in only the older array, old/new represent turtles monitored in the old and reformed array, and new represents turtles monitored in only the reformed array. SCL: straight carapace length. Data analysis: $a, b$, and/or $c$ indicate which turtles were used in the 'movements from the basin to the river,' 'departures from the river,' and/or 'within-river movements' analyses, respectively. -: turtle was not used for any analysis. ${ }^{*} \mathrm{~T} 1, \Delta \mathrm{T} 8$, and $\bullet \mathrm{T} 10$ are recaptured turtles

\begin{tabular}{|c|c|c|c|c|c|c|}
\hline $\begin{array}{l}\text { Turtle } \\
\text { no. }\end{array}$ & $\begin{array}{c}\text { Site } \\
\text { tagged }\end{array}$ & Date monitored & $\begin{array}{l}\text { No. days } \\
\text { monitored }\end{array}$ & Array & $\begin{array}{c}\text { Size } \\
(\mathrm{SCL}, \mathrm{cm})\end{array}$ & Data analysis \\
\hline *T1 & San Gabriel R. & 25 Jun 2012-4 Jul 2012 & 10 & Old & 71.1 & - \\
\hline $\mathrm{T} 2$ & $7^{\text {th }}$ St. Basin & 25 Jun 2012-12 Jul 2012 & 18 & Old & 64.2 & $a$ \\
\hline T3 & San Gabriel R. & 25 Jun 2012-17 Aug 2012 & 54 & Old & 66.1 & - \\
\hline $\mathrm{T} 4$ & San Gabriel R. & 25 Jun 2012-21 Sep 2012 & 89 & Old & 96.8 & - \\
\hline T5 & San Gabriel R. & 25 Jul 2012-14 Sep 2012 & 52 & Old & 65.9 & - \\
\hline T6 & San Gabriel R. & 8 Aug 2012-18 May 2014 & 649 & Old/new & 66.3 & $b / c$ \\
\hline $\mathrm{T} 7$ & $7^{\text {th }}$ St. Basin & 8 Aug 2012-24 Mar 2013 & 228 & Old/new & 78.6 & $a / b / c$ \\
\hline$\Delta \mathrm{T} 8$ & San Gabriel R. & 6 Nov 2012-9 Nov 2012 & 4 & New & 56.6 & $b$ \\
\hline T9 & San Gabriel R. & 19 Mar 2013-31 May 2013 & 74 & New & 63.2 & $b / c$ \\
\hline$\bullet \mathrm{T} 10$ & San Gabriel R. & 19 Mar 2013-10 May 2013 & 53 & New & 62.8 & $b / c$ \\
\hline $\mathrm{T} 11$ & San Gabriel R. & 19 Mar 2013-5 Oct 2013 & 201 & New & 45.2 & $b / c$ \\
\hline $\mathrm{T} 12$ & $7^{\text {th }}$ St. Basin & 10 Jul 2013-13 Aug 2013 & 34 & New & 56.8 & $a$ \\
\hline $\mathrm{T} 13$ & $7^{\text {th }}$ St. Basin & 10 Jul 2013-26 Jan 2014 & 201 & New & 62.3 & $a / b / c$ \\
\hline$\Delta \mathrm{T} 8$ & San Gabriel R. & 28 Aug 2013-4 Nov 2013 & 69 & New & 54.8 & $b / c$ \\
\hline $\mathrm{T} 14$ & San Gabriel R. & 28 Aug 2013-1 Nov 2013 & 66 & New & 53.6 & $b / c$ \\
\hline T15 & San Gabriel R. & 28 Aug 2013-16 Mar 2014 & 201 & New & 75 & $b / c$ \\
\hline T16 & San Gabriel R. & 6 Feb 2014-5 Apr 2014 & 59 & New & 60.9 & $b / c$ \\
\hline T17 & San Gabriel R. & 6 Feb 2014-20 Apr 2014 & 74 & New & 61.4 & $b / c$ \\
\hline •T10 & San Gabriel R. & 5 Mar 2014-25 Apr 2014 & 52 & New & 65.6 & $b / c$ \\
\hline T18 & San Gabriel R. & 5 Mar 2014-24 Mar 2014 & 20 & New & 62 & $b$ \\
\hline T19 & San Gabriel R. & 29 May 2014-13 Jul 2014 & 46 & New & 52.7 & $b / c$ \\
\hline${ }^{*} \mathrm{~T} 1$ & San Gabriel R. & 29 May 2014-8 Aug 2014 & 72 & New & 74.3 & $b / c$ \\
\hline T20 & $7^{\text {th }}$ St. Basin & 30 May 2014-11 Jun 2014 & 13 & New & 62.7 & $a / b$ \\
\hline T21 & $7^{\text {th }}$ St. Basin & 5 Aug 2014-20 Aug 2014 & 16 & New & 67.1 & $a$ \\
\hline T22 & $7^{\text {th }}$ St. Basin & 6 Aug 2014-31 Aug 2014 & 26 & New & 50.8 & a \\
\hline
\end{tabular}

again in the river $703 \mathrm{~d}$ later on 29 May 2014. The 2 other recaptures occurred 293 and $300 \mathrm{~d}$ after the first capture.

\section{Movements from the basin to the river}

Four of the 7 turtles tagged in the $7^{\text {th }}$ St. Basin (Table 1) left the detection area in the SBNWR after $76 \pm 41 \mathrm{~d}$ (mean $\pm \mathrm{SE}_{\text {; }}$ used for remainder of paper, unless SD is specified) (2 in the winter: Dec 2012 and Dec 2013; 2 in the summer: June 2012 and June 2014). The other 3 turtles' transmitters either ceased transmitting while the turtle was in the $7^{\text {th }}$ St. Basin or the study ended while the turtles were still in the $7^{\text {th }}$ St. Basin. When turtles left the $7^{\text {th }}$ St. Basin, each represented the only tagged turtle present in the SBNWR at the time. All were detected entering the San Gabriel River after leaving the SBNWR. The 2 tagged turtles that exited the $7^{\text {th }}$ St. Basin in the winter left on 31 December 2012 and 6 December 2013, when the mean $( \pm \mathrm{SD}) 7^{\text {th }} \mathrm{St}$. Basin temperatures $( \pm 1$ $\mathrm{d}$ from departure) were $12.6 \pm 0.06^{\circ} \mathrm{C}$ and $14.5 \pm$ $0.10^{\circ} \mathrm{C}$, respectively. On those dates, mean coastal ocean temperatures $\left(14.0 \pm 0.02^{\circ} \mathrm{C}\right.$ and $16.7 \pm 0.02^{\circ} \mathrm{C}$, respectively) were warmer than the $7^{\text {th }}$ St. Basin; however, mean temperatures of the entire San Gabriel River for those corresponding days were substantially warmer at $15.4 \pm 0.03^{\circ} \mathrm{C}$ and $23.8 \pm 0.12^{\circ} \mathrm{C}$, respectively. Turtles took approximately 27 and $19 \mathrm{~h}$, respectively, to travel $7.2 \mathrm{~km}$ from the $7^{\text {th }} \mathrm{St}$. Basin to the mouth of the river. Their movements were detected by all receivers (Fig. 1) on their way out of the SBNWR and Anaheim Bay. One of the turtles (T2) caught and tagged in the $7^{\text {th }}$ St. Basin (20 June 2012) that moved into the river during the summer had been previously caught in the river prior to this study (18 August 2011). This turtle had moved from the river to the $7^{\text {th }}$ St. Basin and back again at least once in less than a year. This turtle was also the only individual captured that had displayed movement from the river to the $7^{\text {th }}$ St. Basin. The second turtle (T20; tagged on 30 May 2014) that left the $7^{\text {th }}$ St. Basin during the summer was detected in Alamitos Bay (3 June 2014) before it was eventually detected in the river (10 June 2014). After a day in the river the turtle left and was not detected on any receiver array again for the remainder of the study. 


\section{Departures from the river}

Over the study period (duration of reformed array: November 2012 to August 2014) 8 of 15 tagged turtles that were detected in the river exited for $>1 \mathrm{~h}$ a total of 115 times and for a mean duration of $9.8 \pm$ $0.9 \mathrm{~h}$ before returning to the river. While outside the river, one turtle was detected in Anaheim Bay and 3 were detected in Alamitos Bay.

The number of turtles that left the river varied by season. No tagged turtles left the river in the fall; however, this may be the result of fewer tagged turtles during that time of year. At least 2 turtles left during summer, winter and spring. There was no statistical difference in the amount of time (h) turtles spent outside the river among seasons $\left(F_{2,105}=0.260, \mathrm{p}=\right.$ 0.772) (Fig. 2a). The number of river departures per individual was highest in the spring (18 departures) compared to summer (3.5 departures) and winter (4.5 departures) (Fig. 2b). From the beginning of the study in June 2012, 2 turtles left the river and were not detected by any receiver for the remainder of the study.
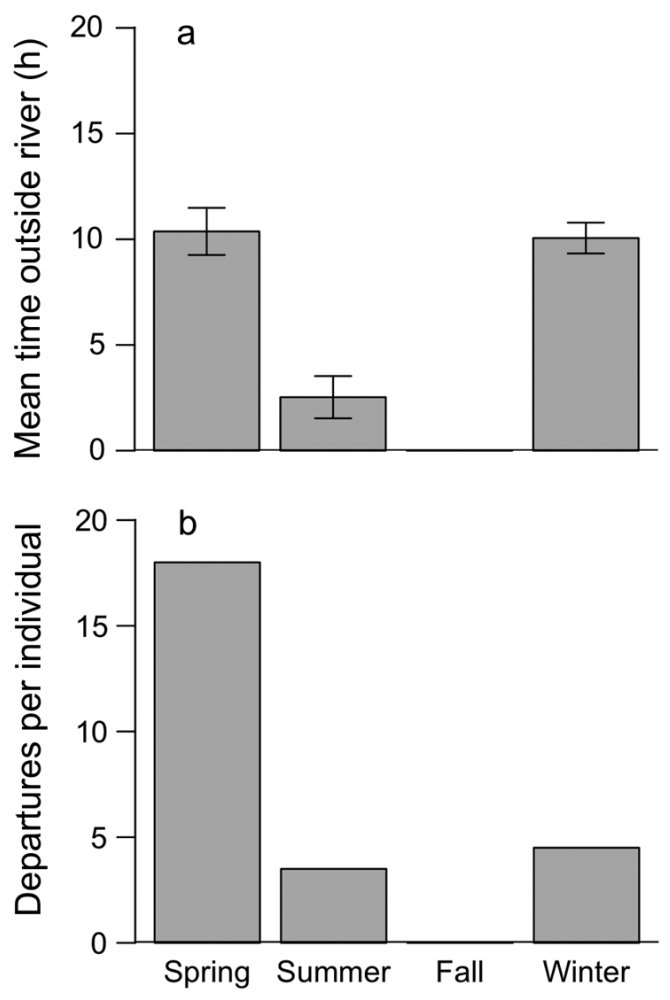

Fig. 2. (a) Mean $( \pm \mathrm{SE})$ time spent outside the river by juvenile green sea turtles Chelonia mydas and (b) the number of the river departures per individual for each season. No turtles left the river during the fall

\section{Within-river movements}

Warm-water effluent use in the San Gabriel River

Of the 15 turtles monitored in the reformed array, 13 were detected in the river for at least $30 \mathrm{~d}$ (Table 1). The mean discharge temperature (temperature of source receiver stations during discharge events) was $26.2 \pm 0.10^{\circ} \mathrm{C}$. In addition, the temperature in the warm-water effluent (extent of the warm water from tidal flow or net river movement) (26.7 \pm $0.04^{\circ} \mathrm{C}$ ) was significantly higher than the temperature outside the warm-water effluent $\left(24.4 \pm 0.03^{\circ} \mathrm{C}\right)$ $\left(F_{1,40517}=2025.30, \mathrm{p}<0.001\right)$. Furthermore, there was also a significantly higher percentage of detections per hour per receiver station in the warm-water effluent $(7.6 \pm 0.16 \%)$ compared to outside the warmwater effluent $(5.8 \pm 0.11 \%)$ when a warm water discharge event occurred $\left(F_{1,40529}=196.63, \mathrm{p}<0.001\right)$.

\section{Presence in the San Gabriel River}

In the winter (Fig. 3b), the highest weekly presence (herein referred to as 'presence') (>50\%) of turtles in the river was in areas adjacent to or downstream of the power plants (from receivers S4 to S9), where warm-water discharge created the warmest available habitat in the river. The largest mean temperature range among receiver stations within a season existed in the winter (range $=1.86^{\circ} \mathrm{C}$ ). The lowest presence of turtles during the winter occurred at the mouth and in areas upstream of the power plants. Unlike during the winter, the lowest presence $(<10 \%)$ of turtles during the summer occurred at receiver stations downstream of the power plants, while the highest presence $(>44 \%)$ in the summer occurred from receiver stations adjacent to the power plant outfalls to the most upstream receiver station (Fig. 3d). In addition, during the summer (Fig. 3d) the locations of the highest presence and lowest presence corresponded exactly with the locations of the warmest and coolest temperatures, respectively. Unlike during the winter and the summer when turtles were found in more discrete areas in the river, the presence of turtles during the spring (Fig. 3c) and fall (Fig. 3a) were more uniform throughout the river. During the spring in particular, the presence at any one receiver station did not exceed $65 \%$ or drop below $15 \%$. During the fall, turtles were found infrequently at the river mouth and moved throughout the rest of the river. Temperatures during the spring and fall were lowest at the mouth, while temperatures 


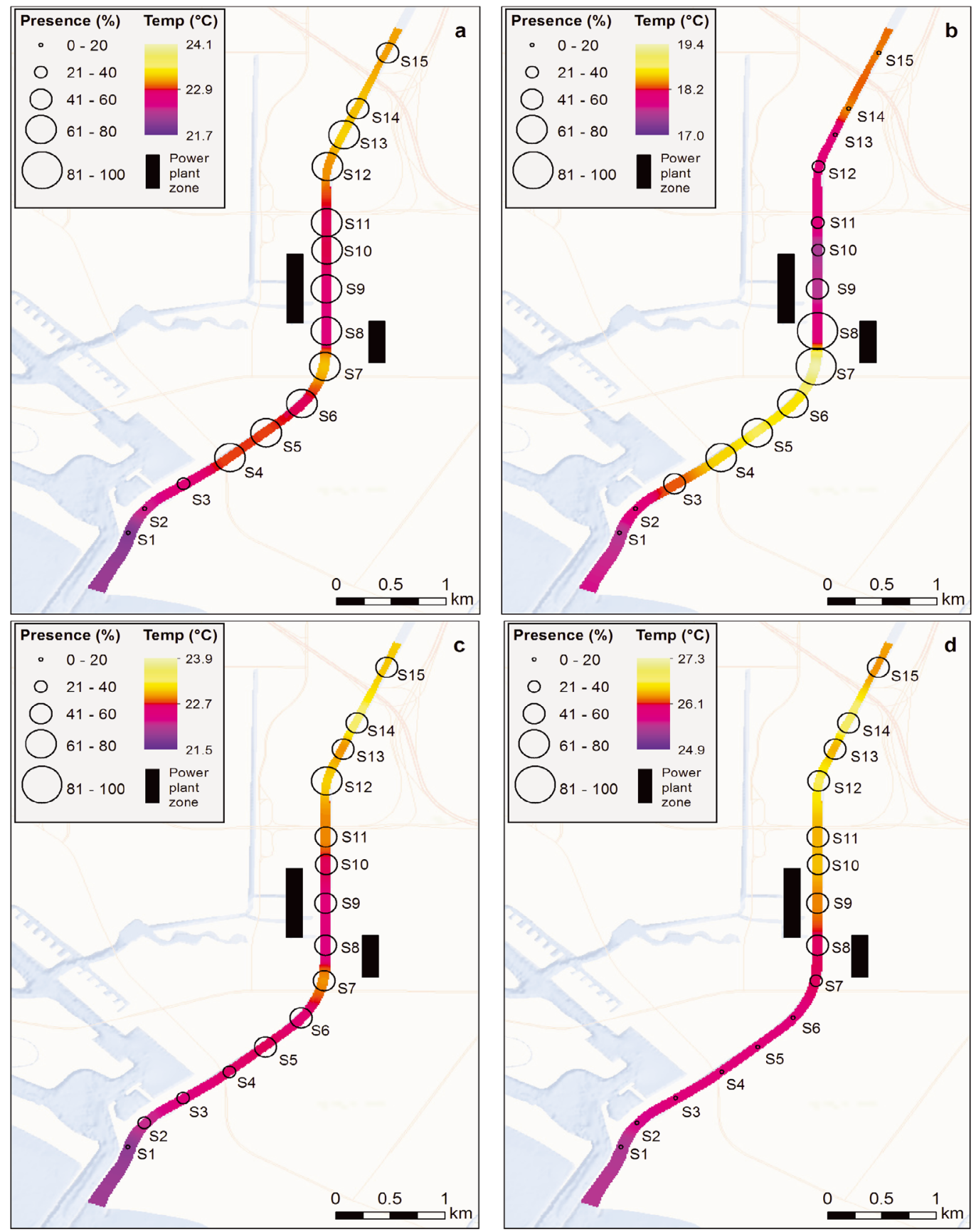

Fig. 3. Mean weekly presence (\%) among all juvenile green sea turtles Chelonia mydas at each receiver station in the San Gabriel River (S1-S15) in the (a) fall, (b) winter, (c) spring, and (d) summer is indicated by the black circles. Mean seasonal temperatures were interpolated throughout the entire river using an inverse distance weighting (IDW) interpolation. Range of the color ramp is the same for each season; however, the high and low temperatures differ among seasons to highlight the relative differences in temperature

were highest farther upstream near the concretelined portion of the river. GAMs were able to statistically prove that temperature influences turtle presence. The deviance explained for GAM I and GAM II (model including temperature) were 45.8 and $66.2 \%$ respectively $\left(F_{3117,3235}=15.98, \mathrm{p}<0.001\right)$.
Mean locations in the San Gabriel River

A distinct pattern existed among the mean locations of turtles in the river throughout the year, with turtles spending more time in the warmest waters in the river (Fig. 4). During the winter months (December, 
Fig. 4. Monthly mean locations in the river of all juvenile green sea turtles Chelonia mydas from November 2012 to August 2014 (black dots) overlaying standardized temperatures from the mouth of the San Gabriel River $(0 \mathrm{~m})$ to the concretelined portion of the river $(6300 \mathrm{~m})$. Temperatures were standardized by dividing each mean station temperature in a month by the mean maximum temperature that month. Bars around each monthly mean location in the river represent the interquartile range $(50 \%$ core area) of all locations from all tagged turtles for each month

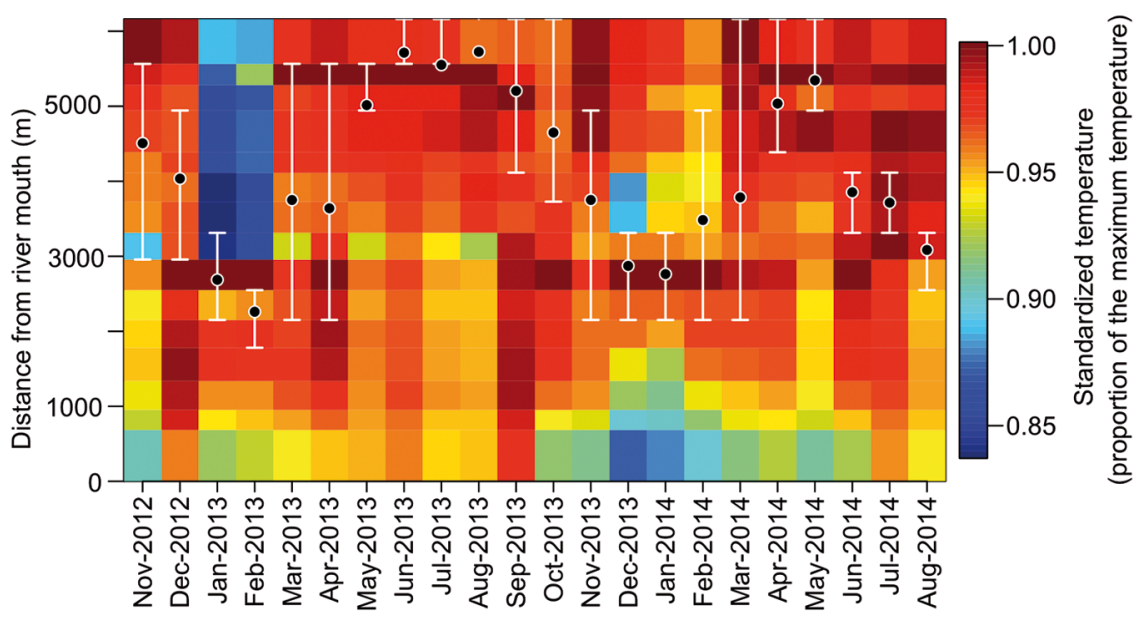

January, February) turtles were often found in areas near or downstream of the power plants' discharge stations ( $3 \mathrm{~km}$ from the river mouth), while not detected in the cooler areas upstream of the power plants and closer to the mouth of the river. This was similar to patterns observed in seasonal presence during the winter months (Fig. 3b), where the highest presence of turtles and the warmest water temperatures were found at receiver location S7 ( 3 km from the river mouth). During the warmer months in 2013, turtles used areas upstream of the power plants; however, in 2014 turtles used areas closer to the power plant discharge stations. Despite a difference in mean locations in the river between the 2013 and 2014 summers, there was still a significant correlation $(\mathrm{p}<0.01$; $\mathrm{r}=0.57, \mathrm{n}=22$ ) between mean location in the river each month and the location of the receiver station with the highest mean temperature each month (Fig. 5). The majority (82\%) of the highest temperatures over the 22 mo study period occurred in 2 distinct areas within the river: the area just downstream of the power plants and the area just downstream of the concrete-lined portion of the river. This latter area receives heated freshwater that has flowed over concrete-lined stretches upstream.

Hourly mean location of turtles in the river was significantly affected by season $\left(F_{3,69}=1544.20\right.$, p < $0.001)$ and hour $\left(F_{23,69}=5.60, \mathrm{p}<0.001\right)$. Similar to monthly mean locations in the river, hourly mean location was significantly different among all seasons ( $p<0.05$ ), with turtles occupying areas farthest upstream in the summer $(5288 \mathrm{~m}$ upstream from the river mouth), $725 \mathrm{~m}$ downstream of that in the fall, $331 \mathrm{~m}$ downstream of that in the spring, and an additional $1347 \mathrm{~m}$ downstream of that in the winter (Fig. 6). Although the hourly mean locations in the river changed with season, diel movement patterns were similar among seasons, where in the morning (after 06:00 h), turtles gradually moved downstream until late afternoon (14:00-17:00 h) at which time, turtles migrated quickly upstream and reached their destination by late evening (19:00-23:00 h) (Fig. 6). Hourly mean locations were significantly farther upstream in the early morning (Tukeys: $p<0.05$ ) and late evening (Tukeys: $\mathrm{p}<0.05$ ) compared to the later afternoon. To determine whether there was a certain time of day in which turtles migrated upstream, the hour in which the farthest downstream mean location occurred each day for $634 \mathrm{~d}$ (November 2012-August 2014) was identified. Then, the number of days during which the farthest downstream mean location occurred per hour was compared to a uniform distribution across hours each day for $634 \mathrm{~d}$. There was a significant difference between observed and random data $\left(\chi^{2}=104.09, \mathrm{df}=23, \mathrm{p}<0.001\right)$, with the highest frequencies of farthest downstream mean locations in the river occurring between 14:00 and 17:00 h.

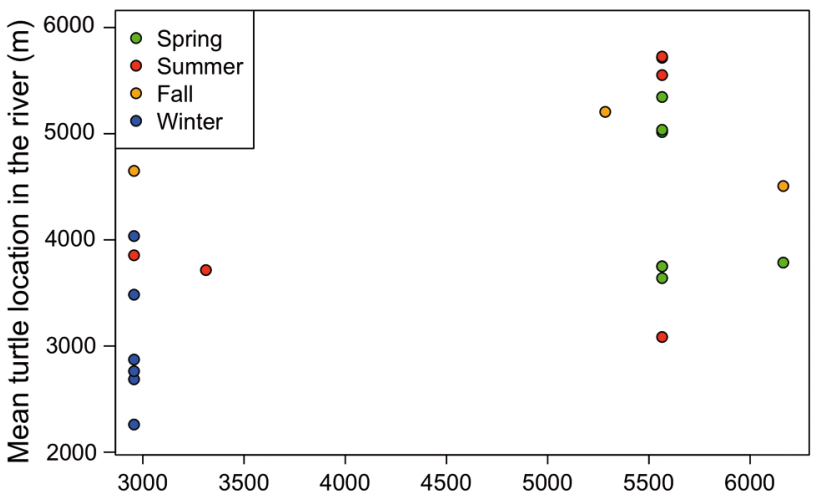

Receiver station location of the highest average river temp ( $\mathrm{m}$ )

Fig. 5. Monthly mean location in the river of juvenile green sea turtles Chelonia mydas (ordinate) against the location of the highest mean temperature (abscissa) from November 2012 to August 2014 




Fig. 6. Hourly mean location in the river of all juvenile green sea turtles Chelonia mydas from 00:00 to 23:00 $\mathrm{h}$ for each season: (a) fall, (b) winter, (c) spring, (d) summer. Dashed lines represent the interquartile range (50\% core area) of all hourly locations in the river for each season

\section{Activity (maximum river use) in the San Gabriel River}

The model with minimum temperature and month was the best model according to AIC (Table 2). The lowest maximum river use was during the warmer months (June-September) when minimum temperatures ranged from 18 to $19.6^{\circ} \mathrm{C}$ (Fig. 7). The highest maximum river use was from the late fall to the spring (November-April) (Fig. 7).

\section{DISCUSSION} $\triangle \mathrm{AIC}$ represents the difference between each model's AIC and the model with the lowest AIC. AIC: Akaike's information criterion

\begin{tabular}{|llc|}
\hline Model no. & \multicolumn{1}{c|}{ Model variables } & $\Delta$ AIC \\
\hline 1 & month, minimum temp. & 0 \\
2 & month, temp. standard deviation & 4.73 \\
3 & month, mean temp. & 17 \\
4 & month, median temp. & 20.59 \\
5 & month, maximum temp. & 29.98 \\
6 & month & 161.44 \\
\hline
\end{tabular}



Fig. 7. Chelonia mydas. Monthly mean maximum river use values each month in a year are indicated by large black dots. Smaller grey dots represent daily maximum river use values from each tagged turtle each month. Numbers next to the black dots represent the number of tagged turtles that month. The red and blue lines represent the mean and minimum temperatures, respectively
This residential foraging aggregation of eastern Pacific GSTs is currently living at the northern limit of its range and is therefore confronted with temperatures that push its physiological limits. To avoid the colder temperatures and associated physiological stress, it appears juvenile GSTs are seeking out warmer habitats that provide a thermal refuge during colder months. These results demonstrate that the San Gabriel River offers a year-round habitat for GSTs, while the $7^{\text {th }}$ St. Basin offers only a seasonally available habitat (spring to the fall). Based on the duration of the 3 recaptured individuals in the river (days at liberty: 293, 300, 703 d) and a transmitter retention time of $649 \mathrm{~d}$ for T6 (Table 1), it appears GSTs have taken up residency in these habitats. This study not only represents the first detailed record and insight into GST movements and residency in this highly populated urban area, but indicates that they can reside from months to years in areas with high human population density.

\section{Movements from the basin to the river}

The lack of turtle sightings within the $7^{\text {th }}$ St. Basin (K. Gilligan pers. comm.) during winter months, and the departure of all tagged turtles from the $7^{\text {th }}$ St. Basin during the winter, suggest that GSTs are likely leaving this food-rich habitat due to colder temperatures. This temperature-driven migration has been 
observed in the northwest Atlantic, where juvenile Kemp's ridley sea turtles Lepidochelys kempi recruit to shallow coastal habitats off New England and New York in the summer, then migrate south or offshore in the winter to avoid cold temperatures (Musick \& Limpus 1997). In the Mediterranean Sea, loggerhead sea turtles Caretta caretta travel as far as $3000 \mathrm{~km}$ to their overwintering site (Hochscheid et al. 2007).

The movements of the 2 turtles from the $7^{\text {th }}$ St. Basin to the river in the summer may be due to competition for resources among multiple individuals in the relatively small $\left(0.15 \mathrm{~km}^{2}\right) 7^{\text {th }}$ St. Basin. In addition, the shallow waters within the $7^{\text {th }}$ St. Basin frequently exceeded $25^{\circ} \mathrm{C}$ in the warmest month, temperatures which may reduce eelgrass growth due to heat stress (Zimmerman et al. 1989). While these summer temperatures may be better for turtles and enhance their growth rates (increased metabolism) (Eguchi et al. 2012), these temperatures may lower eelgrass productivity and thereby limit food availability at a time when turtles likely feed the most, driving turtles to leave the $7^{\text {th }}$ St. Basin in search of more productive habitats close by.

\section{Departures from the river}

Occasional river departures suggest that turtles might be taking advantage of resources outside the river, although not necessarily in the $7^{\text {th }}$ St. Basin. Alamitos Bay offers considerable foraging habitat along the rock riprap, boat docks, and flats, including eelgrass beds. The breakwaters and ripraps supporting the entrance to Alamitos Bay contain a greater diversity and abundance of encrusting invertebrates and algae than the riprap lining the San Gabriel River; therefore, during spring and warm winter months, when ocean temperatures are warm enough, some juvenile GSTs may forage along those habitats in addition to in the river. However, Alamitos Bay also supports several large marinas with high boat traffic, which increases the likelihood of boat strikes. Other potential habitats for turtles include the Los Angeles River $(9.3 \mathrm{~km}$ northwest of the San Gabriel River mouth) and Bolsa Chica Ecological Reserve $(10.1 \mathrm{~km}$ southeast of the San Gabriel River mouth), where GSTs have been observed, albeit rarely (D. Lawson pers. comm.).

Typically, GSTs that left the San Gabriel River did so during morning hours (08:51 $\pm 0.4 \mathrm{~h})$ and returned in the early afternoon $(15: 23 \pm 0.6 \mathrm{~h})$, suggesting that turtles may be leaving the river to forage at other habitats and then returning to the river to rest at night. This pattern of behavior is different than patterns seen in subtropical/tropical populations of GSTs, which found that individuals would forage in shallow warm habitats and then move to cooler deeper waters to rest (Mendonca 1983, Hazel 2009, Blumenthal et al. 2010). In addition, the majority of these river departures occurred in spring, followed (in frequency) by the winter and summer seasons. An increase in departures in the spring may be due to the depletion of resources during the winter when there may be a higher density of turtles in the river avoiding colder surrounding ocean waters. Nonetheless, when combining all monitoring days of all 15 turtles, individuals only left the river on $5.5 \%$ of the days. In addition, the individual that had a transmitter retention time of $649 \mathrm{~d}$ only left the river on 6 occasions on 4 different days, further supporting the use of the river as a year-round habitat for GSTs.

\section{Within-river movements}

GST presence and mean location in the river both suggest that turtles prefer the warmest areas in the river during the winter, associated with the power plant discharge outflows. The avoidance of colder areas in the river $\left(<15^{\circ} \mathrm{C}\right)$ and use of warmer areas is indicative of thermal refuging, which has been observed in ectotherms and some marine mammals (Bossart et al. 2004, Laist \& Reynolds 2005, MacDonald et al. 2012). In addition to becoming inactive at $15^{\circ} \mathrm{C}$, captive studies have indicated that turtle blood gas concentrations and food consumption declined (Moon et al. 1997), and growth rates slowed as individuals may have been approaching torpor (Mrosovsky 1980, Balazs \& Chaloupka 2004). The warm-water effluent from power plants in the San Gabriel River increased winter temperatures in parts of the river to over $19^{\circ} \mathrm{C}$, and extends downstream and out into the ocean. The warmest thermal effluent stretches from the discharge outflow to approximately $1 \mathrm{~km}$ downstream of power plants, depending on the rate of discharge. This stretch of warm water likely allows turtles to remain relatively active during the coldest months of the year, as observed in the daily maximum river use data. However, a higher density of thermal refuging turtles in areas adjacent to and downstream of the power plants may lead to an increase in competition for resources, which may cause individuals to search out larger, but less thermally beneficial areas where resources may be in greater abundance.

GSTs (mass range: 27-153 kg; size class: 54.9$103 \mathrm{~cm} \mathrm{SCL}$ ) have also been observed thermal refug- 
ing in power plant warm-water effluent in San Diego Bay, where turtles' core areas (50\% utilization distribution) were observed around the power plant discharge area in the winter months (McDonald et al. 1994, MacDonald et al. 2012). Since this power plant was decommissioned in 2010, GSTs have been no longer observed to aggregate in this area, but have redistributed themselves throughout the bay (J. Seminoff pers. comm.). In addition, growth rates of warm-temperate eastern Pacific GSTs in San Diego Bay that utilized this thermal refuge were found to be similar to those of GSTs in the tropical Caribbean (Eguchi et al. 2012). High growth rates within San Diego Bay turtles suggest that the warm-water thermal refuge may have led to a higher metabolic rate, resulting in an increase in food consumption and growth (Eguchi et al. 2012).

Even in the summer months, when the lowest temperatures within the San Gabriel River exceeded $25^{\circ} \mathrm{C}$, turtles still displayed the highest presence in the warmest areas of the river. Despite the warmwater discharge from the power plants, turtles still located even warmer $\left(>26^{\circ} \mathrm{C}\right)$ areas within the upper reaches of the river upstream of the power plants. Temperatures as high as $31^{\circ} \mathrm{C}$ have been recorded when freshwater flow was limited and the shallow slow-moving heated water flows over the concretelined segments of the San Gabriel River and drains into the estuarine portion of the river. During the summer months, turtles rarely visited areas downstream of the power plants and near the mouth of river. Interestingly, turtles occupied areas above the upper temperature threshold where they can become inactive $\left(25-28^{\circ} \mathrm{C}\right)$ (Heath \& McGinnis 1980, Spotila et al. 1997). Movement data suggest that turtles used shorter stretches (maximum river use) per day in the summer. Reducing the amount of activity decreases the amount of heat generated by the muscles, which, in warm water, may help prevent overheating. Furthermore, temperature throughout the river may be strongly heterogeneous, with pockets of cooler water existing between the locations of temperature loggers. Turtles could seek out these cooler pockets of water in these areas, which would result in a decrease in extent of river use, but would have to provide sufficient food resources. High nutrient runoff in freshwater enters these areas of the estuarine river first, which may lead to higher phytoplankton and macroalgae productivity (Pedersen \& Borum 1996). Therefore, turtles may benefit from an abundance of algae in these warm, highly productive areas during the summer. In addition, the lack of eelgrass in the San Gabriel River may lead to a higher abundance of invertebrates in the diet of GSTs. Lemons et al. (2011) estimated that, based on stable isotope analysis, GSTs in San Diego Bay had the highest signature of invertebrates in their diet compared to any other GST study to date. They speculated that turtles might have been preying on both mobile and sessile invertebrates, to compensate for the lower availability of preferred algae in San Diego Bay.

In the spring and fall months, turtle presence was more uniform throughout the river, compared to the winter and summer. In the spring, turtles may shift from using the warm areas downstream of the power plants to the warmest available river waters upstream of the power plants during the summer. This movement appeared to be reversed during the fall months. This transition was slow and varied among individual turtles. As a result, during these seasons, overall turtle distribution in the river would be wider and more uniform. Lastly, if higher densities of individuals are resulting in a depletion of resources within smaller areas with specifically beneficial temperature ranges during the winter and summer, turtles may choose to search other locations in the river for resources during the spring and fall, while temperatures are not as constraining.

Despite variation in GST distribution among seasons, individuals displayed similar diel shifts each season, whereby during the day turtles would slowly make their way downstream and during late afternoon they would move back upstream, but at a faster rate. This gradual movement downstream may be indicative of moving from one feeding patch to another, while potentially conserving energy as the slow net movement of water pushes them downstream. A similar movement pattern was observed in a bay in Baja California, Mexico where GSTs would move with the tide to exploit the patchy distribution of algae while presumably conserving energy (Brooks et al. 2009). The quick movement upstream observed in the current study during the late afternoon could be the result of several factors: (1) the best resting areas are further up river, (2) the turtles complete foraging and have no need to stop on their way to their resting locations, or (3) while the turtles were foraging, the downstream current pushed turtles into less beneficial water temperatures, which would cause turtles to move back into warmer waters for thermoregulatory purposes. Seasonal foraging and resting habitat differences have not been well documented in GSTs; however, this study demonstrates that these differences may occur within a single river. 
In addition to the foraging aggregations in Long Beach/Seal Beach, CA and San Diego Bay, CA, thermal selection has also been observed in adult loggerhead turtles at the northern extent of their breeding range, where individuals take advantage of thermal hotspots within a highly dynamic thermal environment (Schofield et al. 2009). It seems short distance movements to satisfy behavioral thermoregulation may occur quite widely in sea turtles, particularly at their latitudinal range limits where waters are often highly productive. If turtles are unable to find a thermal refuge, whether it be from anthropogenic (present study and MacDonald et al. 2012) or winddriven (Schofield et al. 2009) sources, individuals may need to make further migrations or remain at their overwintering site longer, as seen in multiple sea turtle species (McMahon \& Hays 2006, Hawkes et al. 2007, Hochscheid et al. 2007). By minimizing or eliminating migration, turtles reduce time and energy costs, which can otherwise be allocated to processes such as growth and reproduction.

\section{CONCLUSIONS}

This study documents the movement patterns of the northernmost foraging aggregation of eastern Pacific GSTs reported to date within the San Gabriel River in Long Beach, CA and the $7^{\text {th }}$ St. Basin, SBNWR, Seal Beach, CA. Unlike the foraging aggregation in San Diego Bay, where adult and juvenile individuals are present, this aggregation within Long Beach and Seal Beach is comprised primarily of juvenile turtles, suggesting that these habitats offer adequate resources for juvenile turtles, but perhaps not adults. Reports of GSTs within San Diego Bay extend as far back as the late 1800s (McDonald et al. 1994), while accounts of GSTs in the San Gabriel River only go back as far as 50 yr ago (D. Reish pers. comm.), which was around the time the power plants were installed $(\sim 1950$ s) along the San Gabriel River. The thermal characteristics (warmer than surrounding waters) of the San Gabriel River and the $7^{\text {th }}$ St. Basin may allow individuals to stay and grow yearround as long as conditions and food availability remain suitable this far north. However, the manner by which individuals have found these areas this far north is unknown. It may be by chance that these juvenile turtles were carried from their nesting beaches in Mexico by prevailing currents (Scott et al. 2014) and recruited in this area, where warm water discharge allowed them to remain. If not for these AAWT, turtles may have been cold-stunned and died, which is common at higher latitudes (Witherington \& Ehrhart 1989). In addition, recruitment to these more northern habitats may become more common as global climate change continues to increase ocean temperatures.

Warm-water discharge from power plants may be sustaining this year-round residential aggregation of juvenile GSTs this far north. With power plants required to discontinue their OTC systems by 2029, these findings suggest that GSTs may be forced to migrate to warmer southern waters during colder winter months, where they may be susceptible to greater boating interactions.

Acknowledgements. Financial support was provided by the NOAA Fisheries West Coast Regional Office, SCTC Marine Biology Foundation, and the Los Angeles Rod and Reel Club. We thank US Fish and Wildlife manager K. Gilligan, US Navy Ecologist B. Schallmann, and Los Cerritos Wetlands for logical support. We also thank the following individuals for their support in the field: D. Prosperi, J. Schumacher, B. MacDonald, and the entire NOAA-NMFS team that assisted with turtle capture. We especially thank numerous volunteers who helped with data-collection, including J. Hinricher, A. Jimenez, C. White, and W. Stahnke. We particularly thank D. Johnson, J. Archie, and T. Fahy for their input and guidance during the project. All research and animal handling was carried out under the National Marine Fisheries Service Permit \#14510

\section{LITERATURE CITED}

Allen AO, Feddema JJ (1996) Wetland loss and substitution by the Section 404 permit program in southern California, USA. Environ Manage 20:263-274

Balazs GH, Chaloupka M (2004) Spatial and temporal variability in somatic growth of green sea turtles (Chelonia mydas) resident in the Hawaiian Archipelago. Mar Biol 145:1043-1059

Blumenthal JM, Austin TJ, Bothwell JB, Broderick AC and others (2010) Life in (and out of) the lagoon: fine-scale movements of green turtles tracked using time-depth recorders. Aquat Biol 9:113-121

> Bossart GD, Meisner RA, Rommel SA, Lightsey JD, Varela RA, Defran RH (2004) Pathologic findings in Florida manatees (Trichechus manatus latirostris). Aquat Mamm 30:434-440

Brooks LB, Harvey JT, Nichols WJ (2009) Tidal movements of East Pacific green turtle Chelonia mydas at a foraging area in Baja California Sur, México. Mar Ecol Prog Ser 386:263-274

Eguchi T, Seminoff JA, LeRoux RA, Dutton PH, Dutton DL (2010) Abundance and survival rates of green turtles in an urban environment: coexistence of humans and an endangered species. Mar Biol 157:1869-1877

Eguchi T, Seminoff JA, LeRoux RA, Prosperi D, Dutton DL, Dutton PH (2012) Morphology and growth rates of the green sea turtle (Chelonia mydas) in a northern-most temperate foraging ground. Herpetologica 68:76-87

Felger RS, Cliffton K, Regal PJ (1976) Winter dormancy in sea turtles: independent discovery and exploitation in 
the Gulf of California by two local cultures. Science 191: 283-285

Hastie TJ, Tibshirani RJ (1990) Generalized additive models, Vol 43. CRC Press

- Hawkes LA, Broderick AC, Coyne MS, Godfrey MH, Godley BJ (2007) Only some like it hot-quantifying the environmental niche of the loggerhead sea turtle. Divers Distrib 13:447-457

> Hazel J (2009) Evaluation of fast-acquisition GPS in stationary tests and fine-scale tracking of green turtles. J Exp Mar Biol Ecol 374:58-68

Heath ME, McGinnis SM (1980) Body temperature and heat transfer in the green sea turtle, Chelonia mydas. Copeia 767-773

Heupel MR, Yeiser BG, Collins AB, Ortega L, Simpfendorfer CA (2010) Long-term presence and movement patterns of juvenile bull sharks, Carcharhinus leucas, in an estuarine river system. Mar Freshw Res 61:1-10

Hight BV, Lowe CG (2007) Elevated body temperatures of adult female leopard sharks, Triakis semifasciata, while aggregating in shallow nearshore embayments: evidence for behavioral thermoregulation? J Exp Mar Biol Ecol 352:114-128

Hochscheid S, Bentivegna F, Bradai MN, Hays GC (2007) Overwintering behaviour in sea turtles: dormancy is optional. Mar Ecol Prog Ser 340:287-298

$>$ Hothorn T, Bretz F, Westfall P (2008) Simultaneous inference in general parametric models. Biom J 50:346-363

> Jirik KE, Lowe C (2012) An elasmobranch maternity ward: female round stingrays, Urobatis halleri, use warm, restored estuarine habitat during gestation. J Fish Biol 80:1227-1245

Kelso JRM, Milburn GS (1979) Entrainment and impingement of fish by power plants in the Great Lakes which use the once-through cooling process. J Gt Lakes Res 5: 182-194

Laist DW, Reynolds JE III (2005) Florida manatees, warmwater refuges, and an uncertain future. Coast Manage 33:279-295

Lemons G, Lewison R, Komoroske L, Gaos A and others (2011) Trophic ecology of green sea turtles in a highly urbanized bay: insights from stable isotopes and mixing models. J Exp Mar Biol Ecol 405:25-32

Leopold LB (1968) Hydrology for urban land planning: a guidebook on the hydrologic effects of urban land use, US Dept of the Interior, Washington, DC

Ma S, Kueh C, Chiu G, Wild S (1998) Environmental management of coastal cooling water discharges in Hong Kong. Water Sci Technol 38:267-274

> MacDonald BD, Lewison RL, Madrak SV, Seminoff JA, Eguchi T (2012) Home ranges of East Pacific green turtles Chelonia mydas in a highly urbanized temperate foraging ground. Mar Ecol Prog Ser 461:211-221

McDonald D, Dutton P, Mayer D, Merkel K (1994) Review of the green sea turtles of south San Diego Bay in relation to the operations of the SDG\&E South Bay Power Plant. San Diego Gas \& Electric Co, San Diego, CA

McMahon CR, Hays GC (2006) Thermal niche, large-scale movements and implications of climate change for a critically endangered marine vertebrate. Glob Change Biol 12:1330-1338

Mendonca MT (1983) Movements and feeding ecology of immature green turtles (Chelonia mydas) in a Florida lagoon. Copeia 1013-1023

Moon DY, MacKenzie DS, Owens DWM (1997) Simulated hibernation of sea turtles in the laboratory: I. Feeding, breathing frequency, blood $\mathrm{pH}$, and blood gases. J Exp
Zool 278:372-380

> Mrosovsky N (1980) Thermal biology of sea turtles. Am Zool 20:531-547

Musick J, Limpus C (1997) Habitat utilization and migration in juvenile sea turtles. In: Lutz $\mathrm{P}$, Musick J (eds) The biology of sea turtles, Vol 1. CRC Press, Boca Raton, FL, p 137-163

Pedersen MF, Borum J (1996) Nutrient control of algal growth in estuarine waters. Nutrient limitation and the importance of nitrogen requirements and nitrogen storage among phytoplankton and species of macroalgae. Mar Ecol Prog Ser 142:261-272

Pinheiro J, Bates D, DebRoy S, Sarkar D (2013) nlme: linear and nonlinear mixed effects models. R package v.3.1111. http://CRAN.R-project.org/package=nlme

Schofield G, Bishop CM, Katselidis KA, Dimopoulos P, Pantis JD, Hays GC (2009) Microhabitat selection by sea turtles in a dynamic thermal marine environment. J Anim Ecol 78:14-21

Scott R, Marsh R, Hays GC (2014) Ontogeny of long distance migration. Ecology 95:2840-2850

- Seminoff JA, Resendiz A, Nichols WJ, Jones TT, Guyer C (2002) Growth rates of wild green turtles (Chelonia mydas) at a temperate foraging area in the Gulf of California, Mexico. Copeia 2002:610-617

Seminoff JA, Allen CD, Balazs GH Dutton PH and others (2015) Status review of the green turtle (Chelonia mydas) under the US Endangered Species Act. NOAA Tech Memo, NOAA-NMFS-SWFSC-539

Simpfendorfer CA, Heupel MR, Collins AB (2008) Variation in the performance of acoustic receivers and its implication for positioning algorithms in a riverine setting. Can J Fish Aquat Sci 65:482-492

> Southwood AL, Darveau CA, Jones DR (2003) Metabolic and cardiovascular adjustments of juvenile green turtles to seasonal changes in temperature and photoperiod. J Exp Biol 206:4521-4531

Spotila JR, Standora EA (1985) Environmental constraints on the thermal energetics of sea turtles. Copeia 694-702

Spotila J, O'connor M, Paladino F (1997) Thermal biology. In: Lutz P, Musick J (eds) The biology of sea turtles. CRC Press, Boca Raton, FL p 297-314

> Standora EA, Spotila JR, Foley RE (1982) Regional endothermy in the sea turtle, Chelonia mydas. J Therm Biol 7 : $159-165$

Turner CH, Strachan AR (1969) The marine environment in the vicinity of the San Gabriel River mouth. Calif Fish Game 55:53-68

> Turner-Tomaszewicz C, Seminoff JA (2012) Turning off the heat: impacts of power plant decommissioning on green turtle research in San Diego Bay. Coast Manage 40: 73-87

Wallace BP, Jones TT (2008) What makes marine turtles go: a review of metabolic rates and their consequences. J Exp Mar Biol Ecol 356:8-24

Witherington BE, Ehrhart LM (1989) Hypothermic stunning and mortality of marine turtles in the Indian River Lagoon System, Florida. Copeia 696-703

- Wood SN (2006) On confidence intervals for generalized additive models based on penalized regression splines. Aust NZ J Stat 48:445-464

Wood SN (2011) Fast stable restricted maximum likelihood and marginal likelihood estimation of semiparametric generalized linear models. J R Stat Soc B 73:3-36

Zimmerman RC, Smith RD, Alberte RS (1989) Thermal acclimation and whole-plant carbon balance in Zostera marina L. (eelgrass). J Exp Mar Biol Ecol 130:93-109 